\title{
Intra-organizational marketing as a factor in the competitiveness and sustainable development of research and project institute
}

\author{
Irina Nizamova, Tatyana Minina, Olga Popova, and Natalia Izakova \\ Ural State University of Economics, 8th of March Str., 62, 620144 Ekaterinburg, Russia
}

\begin{abstract}
Employees are the intellectual capital of the organization, they are the strategic resource that ensures the achievement of its commercial goals. The formation of employee loyalty allows the organization to ensure its ability to function consistently in the market, to be profitable and competitive, ensuring its corporate sustainability. The article presents the method of forming intra-organization marketing of the organization on the basis of the application of a competent approach. The study presented in the article was based on the research and project institute. The results of the study suggest that the use of a competent approach in the formation of the system of intra-organization marketing affects its effectiveness, expressed in increasing the satisfaction of domestic consumers and, as a result, increasing the satisfaction of external consumers. This contributes to improving the competitiveness and corporate sustainability of the organization as a whole. The positive result of the study was confirmed by an increase in the performance of the system of intra-organization marketing and economic efficiency of the organization.
\end{abstract}

\section{Introduction}

The need to successfully develop the business, attract and retain customers dictates to organizations the choice of effective forms and methods to increase competitiveness and corporate annotation. Employees are the intellectual capital of the organization, they are the strategic resource that ensures the achievement of its commercial goals. The formation of employee loyalty allows the organization to ensure its ability to function consistently in the market, to be profitable and competitive, ensuring its corporate sustainability. In order for the organization to fully meet the needs of external consumers, management needs to ensure that the needs of its domestic customers (employees) are fully met. One of the most effective tools to achieve this goal is intra-organization marketing.

The system of intra-organization marketing allows to meet the needs not only of internal, but also external consumers of the organization's services. A significant competitive advantage and corporate stability in the market can be obtained only if the internal consumers of the company - its employees have a clear understanding of the values and goals of the organization. 
The aim of the study is to prove that applying a competent approach in the formation of the system of intra-organization marketing will contribute to improving the competitiveness and corporate sustainability of the organization.

The study hypothesis is that a competent approach will enable the organization to achieve consistency in the activities of its employees, improve their interactions, ensure high standards of service quality and efficiency, thereby contributing to the competitiveness and corporate sustainability of the organization.

To achieve its goal, the organization's management should assist its employees in developing their key competencies for success, meet the expectations of employees, increase their level of satisfaction and loyalty to the organization, ensuring its competitiveness and sustainable development.

The essence of a competent approach is to develop and implement in the activities of the organization and its employees a set of key competencies that allow employees to effectively perform their duties in accordance with the corporate goals and strategic objectives of the organization. [1]

The role of a competent approach in the system of intra-organization marketing is to maintain a high level of competitiveness and corporate sustainability of the organization by increasing the satisfaction of internal and external consumers.

\section{Materials and Methods}

The term "competence" is associated with Aristotle, who explored the possibilities of man, related to the characteristic features of his personality" [8].

This definition was first formulated by Robert White (1959). In his scientific work " Motivation reconsidered: The concept of competence" he defined competence as human interaction with the external environment [20].

As a result of an in-depth analysis of existing approaches to the concept of "competence," we have developed an author's definition.

Competence is the ability of an organization employee to shape and effectively implement their competences in the face of ever-changing internal and external factors, reflecting the level of his authority in a particular area.

As noted earlier, the main objective of the intra-organization marketing system is to increase the level of satisfaction of domestic consumers so that they can and want to meet the needs of external consumers as effectively as possible. Given the duality of the concept of intra-organization marketing, which implies the organization's focus on both external and internal customers, we have concluded that it is an in-departmental marketing important factor in ensuring the competitiveness and corporate sustainability of the organization.

M. Bruhn writes that "this is achieved by raising the level of employee awareness of the corporate goals and objectives of the organization, ensuring a connection between the organization and its market partners". [19]

The main difficulty associated with the introduction of in-control marketing in the organization is the need to overcome human barriers. In many cases, the organization's offer of services that do not meet the needs of consumers is due to a lack of understanding on the part of employees of the importance of customer orientation, the need to build longterm relationships, low efficiency of the motivation system, and problems of organizational, structural and personnel nature.

Russian scientist E.P. Golubkov notes that psychological barriers are expressed in the absence of market motivation in a large part of managers. [2].

Thus, the goals of the organization are often not achieved due to lack of investment in the development of employees, does not establish the authority and responsibility of each employee and the possibility of his personal contribution to the success of the project. 
There are several components to the process of forming an organization's system of inbody marketing:

-Implementation of two types of management processes:

Relationship management (intra-organization marketing manages the attitude of staff to the service and motivation of consumers) and the management of intra-company communications (forms a system of staff motivation).

Management needs to create an internal atmosphere in which each employee is involved in the process of achieving the organization's goals. Support can also be expressed in the development of training programs, the creation of feedback channels, the formation of a system of bilateral communications in the form of formal and informal interactions.

The issue of determining key competencies is important - different authors have their number varies from three to one hundred and forty. In our view, in order for competence to be classified as key, it must meet the following criteria:

-to be of value to customers. It is necessary to consider whether the employee's skills create an added value of the product offered by the organization through the formation of the value perceived by consumers;

- -to reduce the costs of the organization and increase its profitability and competitiveness. Key competencies should be focused not only on increasing value for consumers, but also on increasing the value of the organization to its employees;

- the skills and skills of the organization's employees must be unique to make it difficult for competitors to copy. Key competencies should be focused on creating unique products;

- $\quad$-key competencies should be based on knowledge, not coincidence, and involve several activities or products;

- -these competences should ensure the organization's transition to tomorrow's markets. Employees should have an idea of how the competency at the heart of this product can be used not only to create an existing product, but also to produce a new product and create a new key competency.

Thus, the key must be given to competencies of high value to the organization's internal and external consumers, and they must be unique and aimed at shaping and meeting future needs.

Based on the analysis of the information provided, we can formulate an author's approach to the concepts of competence and key competence.

Competence is a set of knowledge, skills and skills that enable you to do a particular job at a particular point in time. The distinctive definition is the emphasis on limitations in time and space.

Key competence is a combination of unique knowledge, skills, skills and qualities of the organization's employees, which ensure employee satisfaction, competitiveness and sustainable market development in the long term.

Analysis of the literature studied and experience of practical activities, allowed us to determine the role of competent approach in the system of intra-organization marketing:

-introducing a competent approach to the organization's in-department marketing system reduces the cost of recruiting employees, as in addition to taking into account the level of education and having some experience in a particular area, it involves taking into account the compliance of a potential employee with corporate goals and the objectives of the organization. The presence of the applicant for the position of the relevant corporate competences, gives him a significant advantage over other applicants;

- a competent approach introduced into the organization's in-the-company marketing system allows for the development of unique employee training and development programmes in which expertise is designed to improve their satisfaction. To this 
end, key competencies need to be developed for each segment of the organization's employees;

- the introduction of a competent approach into the organization's in-house marketing system provides an opportunity to form an effective motivational program. The organization's motivational program should be aimed at ensuring a link between the level of competence of employees and the level of their pay.

Unlike the HR system, where the primary objective is to recruit, train and motivate staff to perform their duties, in the in-house marketing system, the main task is to meet the needs of internal customers so that they can meet the needs of external clients as effectively as possible.

Intra-organization marketing plays a special role in the mechanism of interconnecting the orientation of the organization's internal and external consumers in order to meet their needs.

Thus, the satisfaction of external consumers largely depends on the level of satisfaction of internal consumers of the organization, and the satisfaction of domestic consumers is ensured by the level of satisfaction of external, formed a vicious circle.

The author's approach to the formation of a system of intra-organization marketing based on the development of key competencies is based on the application of scientific approaches of Kotler F., Grenroos K. in terms of understanding the essence of intraorganization marketing, L. Spencer in part model competencies, D. McClelland in terms of motivation.

In terms of assessing the level of satisfaction of the research and project institute staff, we use the idea of their segmentation to take into account the characteristics of each target audience. This idea is described in the works of such scientists as: P. Ahmed and M. Rafik, Nadezhdina V., Lobanov D., UvarovA M. [3, 18, 12, 17].

The key indicator of marketing effectiveness, according to most authors, is consumer satisfaction. This opinion is expressed by Kotler F., Lamben J.-J, Doyle P, Deming E, Drucker P. [10, 11, 6, 7, 4,].

Also in the study, we use the E. Novatorov's "Importance - Performance" method, which allows us to assess the effectiveness of in-house marketing in the organization through staff satisfaction, and to understand the main causes of employee satisfaction and dissatisfaction. This will help to develop recommendations for effective intra-organization marketing and to improve the competitiveness and sustainability of the organization.

The research was carried out on the basis of the research and project institute, which conducts design and research activities for metallurgical, mining and processing plants.

The total number of staff of the institute is 450 people. The management of the organization is constantly carrying out a serious technological modernization.

In the first phase of the study, a list of indicators of the effectiveness of intraorganization marketing of the research and project institute and the economic activities of the organization as a whole was formed.

In the second phase of the study, a model of key competencies was developed by the research and project institute expert council. In order to form an effective system of inhouse marketing, key competencies must be at least key specialists, heads of structural units and top managers.

After a detailed analysis of the tasks aimed at ensuring the high level of competitiveness of the research and project institute and its sustainable development in the market of intellectual-intensive services, a list of key competencies was formed:

- -customer orientation

- -innovative activity

- $\quad$-effective negotiating skills

- the ability to form long-term and mutually beneficial relationships with customers. 
The third phase of the study involved the development and implementation of an intraorganization marketing methodology based on the application of a key competency model. This technique consists of the following blocks:

Block 1 is an intra-organization marketing program aimed at developing key competencies (training, training, etc.).

Block 2 is a procedure for assessing the level of development of key competencies.

Block 3 is a motivational program.

The issue of assessing the effectiveness of in-world marketing is one of the most complex and least developed issues.

Traditionally, the effectiveness of intra-organization marketing is evaluated in terms of its economic efficiency.

The main criterion for the economic efficiency of any system is the degree of consumer satisfaction. Thus, an organization's in-house marketing system can be considered effective when the needs of its employees are most fully met with these limited resources.

Figure 1 shows the mechanism for influencing the effectiveness of in-force marketing on improving the competitiveness and corporate sustainability of the organization.

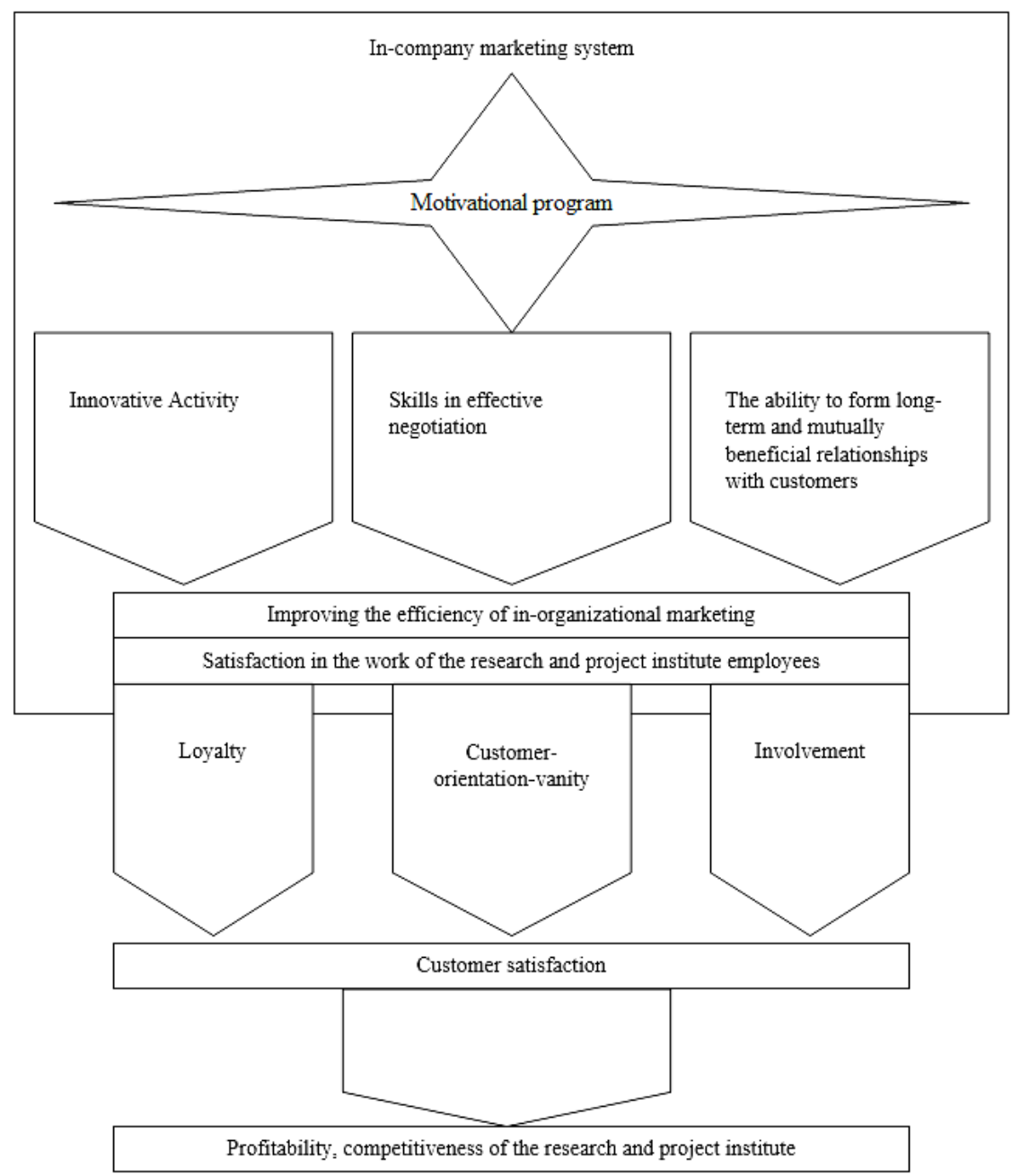

Fig. 1 Mechanism for influencing the effectiveness of intra-organization marketing on improving the competitiveness and corporate sustainability of the organization. 
In the fourth phase, the methodology for forming intra-organization marketing was tested on the basis of the development of key competencies of the research and project institute staff.

\section{Results and Discussion}

To assess the effectiveness of non-organization marketing of the the research and project institute, we have analyzed key elements of intra-organization marketing, such as working conditions, labour content, pay and competence.

We interviewed the organization's employees to investigate their level of satisfaction with their work. The survey results are presented in Table 1.

Table 1. Indicators of the level of satisfaction of the the research and project institute employees by their work for 2009-2019.

\begin{tabular}{|l|c|c|c|c|c|c|c|c|c|c|c|}
\hline Statement & 2009 & 2010 & 2011 & 2012 & 2013 & 2014 & 2015 & 2016 & 2017 & 2018 & 2019 \\
\hline $\begin{array}{l}\text { Work for me } \\
\text { is a reward }\end{array}$ & 50,2 & 65,1 & 67,4 & 67,7 & 76,9 & 80,4 & 81,7 & 81,9 & 79,6 & 86,8 & 96,4 \\
\hline $\begin{array}{l}\text { I get real } \\
\text { pleasure } \\
\text { from work }\end{array}$ & 64,2 & 66,0 & 64,0 & 67,2 & 67,6 & 69,6 & 75,9 & 77,5 & 89,1 & 87,9 & 86,8 \\
\hline $\begin{array}{l}\text { Average } \\
\text { value }\end{array}$ & 57,2 & 65,5 & 65,7 & 67,5 & 72,3 & 75,0 & 78,8 & 79,7 & 84,3 & 87,4 & 91,6 \\
\hline
\end{tabular}

The data presented in Table 1 suggest that staff members are highly satisfied with their work. In 2019, more than $96 \%$ of the research and project institute employees have a need for work per se, compared to only half of the organization's employees in 2009.

Table 2 provides data on employee loyalty to the organization for 2009-2019.

Table 2. Indicators of the level of loyalty to the organization of the research and project institute employees for 2009-2019.

\begin{tabular}{|l|r|r|r|r|r|r|r|r|r|r|r|}
\hline Statement & $\begin{array}{r}200 \\
9\end{array}$ & 0 & 201 & 201 & 201 & 201 & 201 & 201 & 201 & 201 & 2019 \\
\hline $\begin{array}{l}\text { I'm happy with } \\
\text { my current job. }\end{array}$ & 63,5 & 70,0 & 68,9 & 70,8 & 79,2 & 77,1 & 79,7 & 89,5 & 84,6 & 94,0 & 93,1 \\
\hline $\begin{array}{l}\text { At present I can't } \\
\text { imagine another } \\
\text { job }\end{array}$ & 62,3 & 72,3 & 75,6 & 69,0 & 80,2 & 76,0 & 84,7 & 86,4 & 91,8 & 91,9 & 95,1 \\
\hline $\begin{array}{l}\text { I'm not looking } \\
\text { for a new job. }\end{array}$ & 61,2 & 66,3 & 70,9 & 76,1 & 77,4 & 81,5 & 83,0 & 82,0 & 88,7 & 96,8 & 90,6 \\
\hline \begin{tabular}{l} 
Average value \\
\hline
\end{tabular} & 62,3 & 69,5 & 71, & 0 & 78,9 & 78,2 & 82,5 & 85,9 & 88,4 & 94,2 & 92,9 \\
\hline
\end{tabular}

According to Table 2, the level of employee loyalty to the research and project institute has increased significantly by 2019 (from $62 \%$ in 2009 to almost 93\% in 2019).

Table 3 presents performance indicators of the organization's performance, which are ensured by the effectiveness of the intra-organization marketing of the the research and project institute. 
Table 3. Dynamics of the main indicators of the performance of the research and project institute for 2011-2019.

\begin{tabular}{|l|c|c|c|c|c|c|c|c|c|}
\hline & 2011 & 2012 & 2013 & 2014 & 2015 & 2016 & 2017 & 2018 & 2019 \\
\hline $\begin{array}{l}\text { The volume of } \\
\text { goods - in-house, } \\
\text { total, million } \\
\text { rubles, without } \\
\text { VAT }\end{array}$ & 383,9 & 198,5 & 421,2 & 455,8 & 564,4 & 588,0 & 590,0 & 620,8 & 630,5 \\
\hline $\begin{array}{l}\text { Taxes paid, } \\
\text { million rubles. }\end{array}$ & 90,8 & 73,1 & 147,9 & 177,4 & 241,3 & 234,8 & 245,0 & 257,0 & 278,0 \\
\hline $\begin{array}{l}\text { Productivity, } \\
\text { thousand rubles. }\end{array}$ & 83,1 & 43,9 & 92,4 & 98,1 & 117,3 & 121,0 & 138,0 & 147,0 & 151,0 \\
\hline $\begin{array}{l}\text { Satisfaction with } \\
\text { key employees }\end{array}$ & 2,9 & 3,2 & 3,5 & 3,7 & 4,2 & 4,8 & 4,9 & 5,2 & 5,3 \\
\hline $\begin{array}{l}\text { Satisfaction with } \\
\text { non-key } \\
\text { employees }\end{array}$ & 3,0 & 3,1 & 3,3 & 3,4 & 3,9 & 4,0 & 4,0 & 4,3 & 4,6 \\
\hline $\begin{array}{l}\text { Customer } \\
\text { satisfaction }\end{array}$ & 3,9 & 2,0 & 2,6 & 3,5 & 4,3 & 4,8 & 4,9 & 5,1 & 5,3 \\
\hline
\end{tabular}

Table 3 shows that the organization's economic performance is positive. It is also clear from the table that the level of satisfaction of both domestic and external consumers is growing every year. This fact characterizes the high level of effectiveness of the organization's in-government marketing.

\section{Conclusion}

The results of the study suggest that the use of a competent approach in the formation of the system of intra-organization marketing affects its effectiveness, expressed in increasing the satisfaction of domestic consumers and, as a result, increasing the satisfaction of external consumers. This contributes to improving the competitiveness and corporate sustainability of the organization as a whole. The increase in the performance of the system of intraorganization marketing and the economic efficiency of the organization as a whole shows that the application of a competent approach in the formation of the system of intraorganization marketing affects its effectiveness, which confirms the hypothesis of the study.

\section{References}

1. T.A. Vetoshkina, Personnel officer Personnel management, 3, 37 (2008)

2. E.P. Golubkov, Marketing in Russia and abroad, 2, 115 (2002)

3. N. Grishakova, Intrafirm marketing for $H R$ and T\&D specialists, http://www.trainings.ru/

4. E. Deming, New economy, 208 (2006)

5. D. Mc Clelland

6. P. Doyle, Marketing management and strategies, 544 (2002)

7. P. Drucker, The effectiveness of marketing investments - measured using CRM

8. I.A. Zimnyaya, Key competencies as an effective-target basis for a competent approach in education, 40 (2004)

9. Yu. S. Kostrova, Young scientist, 12(2), 102 (2011) 
10. F. Kotler, Marketing management, 800 (2003)

11. Lambin Jean-Jacques, Market oriented management, 800 (2006)

12. D. Lobanov, Internal marketing personnel in the Russian company, http://www.hrportal.ru/

13. John Raven M. Competence in modern society, identification, development and implementation, 396 (2002)

14. Quality Management Systems Requirements ISO 9001: 2008 Quality Management Systems - Requirements (IDT) (2008)

15. Systems, http: // www. iteam.ru/

16. Lyle M. Spencer Jr., Sine M. Spencer, Models of maximum work efficiency, 384 (2010)

17. M. Uvarova, "Human factor" or internal marketing, http://www.logistics.ru/

18. V. Nadezhdina, Effective staff motivation. How to achieve maximum results with minimum costs, 256 (2007)

19. Manfred Brun, Harlow: Financial Times Prentice Hall , 504 (2005)

20. Robert White, Psychological Review, 66(5), 297 (1959) 